\title{
İmam Ebû Hanîfe'nin Siyaset Anlayışı Ve Siyasî Tutumu
}

\section{Dr. Öğretim Üyesi Maksut Çetin}

Gelis tarihi: 27.06.2019

Kabul tarihi: 22.08.2019

\section{Atıf bilgisi:}

IBAD Sosyal Bilimler Dergisi

Sayı: Özel Sayı Sayfa: 25-37

Yıl: 2019

This article was checked by Turnitin. Similarity Index $20 \%$

1İzmir Katip Çelebi Üniversitesi, Turkey cetin_maksut@hotmail.com

ORCID ID: 0000-0002-4851-5412

\section{Sorumlu yazar}

ÖZ

İslam Tarihi boyunca Müslümanlar arasında birçok itikadî, siyasî ve fikhî ekol ortaya çıkmıştır. Bu ekollerden biri Müslümanların büyük çoğunluğunu teşkil eden Ehl-i Sünnet mezhebidir. Onun da en büyük amelî ve fikhî oluşumlarından biri olan Hanefîlik'tir. Bu oluşumun kurucusu olarak kabul edilen İmam Ebû Hanife (ö. 150/767), İslâmî ilimlerin muhtelif dallarında görüş beyan etmiş bir âlimdir. İmam Azam Ebû Hanife'nin itikat ve hukuktan sosyal ve siyasal hayata kadar geniş yelpazede görüş ve fikirleri mevcuttur. Onun düşüncelerini ahlak, sosyal ve siyasal hayattan uzak, İslam toplumunun geçirdiği tarihî aşama ve tecrübelerden arındırılmış sırf itikadî ve fikhî esaslar çerçevesinde değerlendirmek eksik olacaktır. Dolayısıyla Ebû Hanîfe'nin ileri sürdüğü görüşlerinin arka planında bir ahlâkî duruş, içtimaî bütünlük ve siyasî birlik endișesi yattığı söylenebilir. Zira onun fikir ve tutumu, itikadî ve hukukî alanda olduğu gibi ahlâkî, siyasî ve sosyal alanda da incelenmeye değerdir. Ancak görüş beyan ettiği ve tutum takındığı her bir konuyu ele almak, başlı başına bir makale veya kitap konusu olabilir. Dolayısıyla bu çalışmada ele alacağımız konu, onun toplum ve siyasete dair görüş ve tutumlarıdır.

Anahtar Kelimeler: Siyaset, Hukuk, Mezhep, Anlayış, Tutum, İtaat 


\section{The Imam Ebu Hanifah Understanding of Politics and Political Attitude}

\section{Assist. Prof. Dr. Maksut Çetin}

First received: 27.06 .2019

Accepted: 22.08 .2019

\section{Citation:}

IBAD Journal of Social Sciences

Issue: Special Issue Pages: 25-37

Year: 2019

This article was checked by Turnitin. Similarity Index $20 \%$

1 İzmir Katip Çelebi University, Turkey cetin_maksut@hotmail.com

ORCID ID: https://orcid.org/00000002-4851-5412

* Corresponding author

\begin{abstract}
Many Islamic, political and religious schools have emerged among Muslims throughout Islamic history. One of these schools is the Ahl al-Sunnah, which constitutes the majority of Muslims. One of the largest operative and legal formations of these is the Hanafism. Imam Abu Hanifa (d.150 / 767), who is accepted as the founder of this formation, is a scholar who expressed his opinion in various branches of Islamic sciences. It will be incomplete to evaluate his ideas within the framework of purely religious and jurisprudential principles, free from moral, social and political life and free from the historical stages and experiences of Islamic society. Therefore, it can be said that there is a moral stance, social integrity and political unity in the background of Abu Hanif's views. Thus, his ideas and attitudes are worth examining in the moral, political and social fields, as well as in the rhetoric and law. However, to investigate each of the subjects in which he expressed his opinions and attitudes can be a subject of article or book in itself Therefore, the subject that we will discuss in this study is his views and attitudes towards society and politics.
\end{abstract}

Keywords: Politics, Law, Sects, Understanding, Attitude, Obedience. 


\section{GİIŞ}

Siyaset, yönetmek ve birilerinin idaresinden sorumlu olmak demektir. Bu kavram, ilk olarak bir nesnenin iyiliği ve iyileşmesi için özenle gayret gösterme ve onu belli yönde eğitme manasında kullanılmış iken, daha sonraları yönetilenlerin işlerini muhafaza ile hem bir toplumdaki en üst yönetici hem de daha alt kademedeki yöneticiler için kullanılır olmuştur (İbn Manzur, trs., 6, s. 107). Aslında siyaset eşyayı, hayvanları ve insanları idare etme sanatıdır (Bakara, 2/30). Bu kavram, en az biri insan olmak sartıyla ve o insanın ilişkili olduğu diğer bütün nesnelerle olan bağlantıyı ifade eder. Siyaset, "sase" fiilinden türeyen "seyis", yani özne ile siyaset edilen nesne arasındaki ilişki ve o ilişkinin özne tarafindan yönetilmesidir (İbn Manzur, trs., 1, s. 107). Dolayısıyla siyaset öznenin nesneyi yönetmesiyle başlayan bir süreçtir. $\mathrm{Bu}$ süreçte yöneten, yönetilen ve yönetim kavramları arasındaki ilişki siyaset olarak nitelendirilir ki, İslâmî literatürde de bu kavramı genellikle imamet, hilafet, meliklik ve sultanlık gibi kelimelerle ifade edilir (Köse, 2009, s. 294-299; Oral, 2018, s. 926-960).

İnsanlar fitraten toplu halde yaşamak zorundadır. Siyaset, insanoğlunun toplu bir şekilde yaşamak zorunda olmasından kaynaklanan ortak çıkarlarını düzenleyen bir araçtır. Konusu da toplum ve yönetimdir (Akabulut, 2006, s. 1-10). İslam'da siyaset, Müslümanlar üzerinde genel bir tasarruf yetkisidir (el-Makdisî, 1430/2009, s. 413). İslam dininde siyasetin esas gayesi, insanların adaletli bit tarzda mutlu olacakları bir ortamın hazırlanması ve devam ettirilmesi amaciyla hizmet edecek yöneticilerin iş başına getirilmesidir (el-Gazalî, Nasihatü'l-Mülük, 1351, s. 100; es-Semerkandî, trs., s. 473). Bundan dolayı, İslam'da bu görev ve hizmetlerin ifası için hem bir yönetim hem de o yönetimin başında bir yönetici veya yöneticilerin olması zorunlu olarak görülür (el-Gazalî, İhya, 1895, I, 14); etTaftazanî, 1991, s. 259).

İslam dininde siyaset ve siyasî meseleler dinin aslî unsurlarından kabul edilmez, aksine insanlar arası ilişkileri düzenlemeye yönelik olan muamelat konusu olarak kabul edilir (Oral, 2018, s. 926-960). Dinin esasları itikat, ibadet ve ahlaka dairdir. Siyasete taalluk eden kısmı azdır ve ikincildir (Nürsi, İçtmai Dersler, s. 99). Bununla beraber onu dinden tamamen ayrı bir alan olarak kabul etmek de doğru değildir. Özü bakımından aşkın bir boyuta sahip olan din, şartların değişmesiyle değişebilen muamelat konularını, ilkesel bazda ele alır. Onun için siyaset ve siyasete taalluk eden konular, dinin esas meselelerinden kabul edilmez (el-Maturidî, Kitabu't-Tevhid, 2003, s. 285). Bundan dolay1 dinde söz konusu olan muamelat ihtiyaç, menfaat, adalet, zarardan korunma ve hak gibi değerler işığında belirlenir ve düzenlenir (Çelebi, 2010, s. 13). Bu yüzden dinin temel kaynağı olan Kur'an'da hak, liyakat, adalet, itaat ve istişare gibi siyasetin ana esasları dışında, onun teferruatına dair bilgiler bulunmaz. Onun detaylarına ait konular insanların bilgi ve birikimine bırakılmıştır. Ayrıca siyasetin, oransal olarak dindeki yeri çok az olmasına rağmen hem çok çekici hem de diğer dinî ve dünyevî alanları etkileyici bir boyutu vardır. Onun için din-siyaset ilişkisi tarih boyunca çoğu zaman inişli-çıkışlı olmuştur. Bundan dolayı, yöneticilerin görev ve fonksiyonları dinin aslî unsurlarına müdahale değil, teferruatına dair düzenleme ve uygulamalar olmuş ve olmalıdır.

Tarihsel olarak İslam'da, ilk dört halifeden sonra genelde dinin temsilcileri âlimler, siyasetin temsilcileri ise yöneticiler olmuştur. Tarih boyunca İslam âlimlerinin siyasetçilerle ilişkileri ve siyasete dair görüş ve tutumları farklı şekillerde cereyan etmiştir. Bunun en önemli göstergesi hem aynı dönemde ve aynı iktidara karşı farklı âlimlerin farklı görüş ve tutumlar ortaya koymuş olması hem de bir âlimin aynı iktidara karşı farklı dönemlerde farklı kanaat ve tavırlar sergilemiş olmasıdır. Genel olarak ulemanın siyasetle ilişkisi; siyasî otoritenin yanlışlıklarına karşı fiilî olarak isyan edenler ve meydana gelen isyanları destekleyenler, otoritenin yanlışlıklarına sözlü olarak muhalefet edenler, siyasetle isyancılar arasında tarafsız kalanlar ve son olarak siyasetçilerin her türlü uygulamasını onaylayan ve onlardan yana tavır takınanlar şeklinde ortaya çıkmışıı. Dolayısıyla ulemanın fikir ve tutumlarını her zaman yekpare görmek mümkün değildir. Yani onların hem topyekûn hem de bireysel olarak siyasete ilişkin fikir ve tutumlarını belirlemek zordur.

İmam Ebû Hanîfe'nin siyaset ve siyasetçilere karşı tutumunu ve onlara dair görüşlerini belirlemek önemlidir. Ebû Hanîfe, İslam dünyasının kelâm ve fikıh alanında kabul edilen en önemli otoritelerinden biri olmasıyla birlikte, toplumsal ve siyasal görüş ve tutumları da yadsınamayacak kadar değerlidir. Onun siyasete dair görüş ve tutumları hem tarih boyunca din-siyaset ilişkisinde meydana gelen sorunları 
anlama ve anlamlandırma konusunda bizlere rehber olabilir, hem de günümüz ve geleceğe dair bu alanda ulemanın ve toplumun nasıl bir tutum takınması gerektiği hususunda önemli bir ışık tutabilir.

Bu bağlamda Ebû Hanîfe ile ilgili her ne kadar yeterli akademik çalışma yapılmamış olsa da, yine de yüksek lisans ve doktora alanında yapılan birçok araştırmaya rastlamak mümkündür. Örnek olarak; Şükran Karabulut'un Ebû Hanîfe'nin Kader, İnsan Fiilleri ve Büyük Günah Hakkındaki Görüssleri (Yüksek Lisans), Muhammed Boşnak'in Erken Devir İslam Literatüründe Ebû Hanîfe ve Kelâm İlmiyle İlişkisi (Yüksek Lisans), Fatmanur Alibekiroğlu'nun, Ehlu'r-Rey'in İtikadî Boyutu: Eb̂̂ Hanîfe Örneği, (Yüksek Lisans), İsmail Hakkı Ünal'ın, İmam Eb̂̂u Hanîfe'nin Hadis Anlayışı ve Hanefi Mezhebinin Hadis Medodu (doktora) ve Mahmood Hüseyin Ali'nin, İmam Ebû Hanîfe'nin (İmam-ı Azam'ın) İslam Hukuku İle Ilgili Temel Görüşleri (doktora) gibi çalışmalar verilebilir.

\section{Ebû Hanîfe'nin Hayati ve Yaşadiği Sosyo-Politik Ortam}

İmam Azam Ebû Hanîfe'nin asıl ismi Numan b. Sabit'tir. Dinde otoriter, fikıhta Hanefi mezhebinin kurucusu ve itikatta Maturidî ekolunun temelini atan âlimlerdin biridir. Kufe'de 80/699 tarihinde doğmuş (el-Bağdadî, trs., 13, s. 324). Bağdat'ta 150/767 tarihinde vefat etmiştir. Zehirletilerek şehit edildiği de rivayet edilir (es-Saymerî, 1405/1985, I, s. 93). İmam yetmiş yıllık ömrünün büyük bir kısmını Emeviler, geri kalan kısmını ise Abbasiler zamanında geçirmiş (Özel, 2015, s. 15). Hayatının ilk yıllarında, Emevi halifesi Mervan b. Abdülmelik (ö. 65/685) idi. Onun Kufe valisi ise adı tarihte "zalim" olarak kaydedilen Haccac b. Yusuf (ö. 95/714)'tu. Siyaseten bu dönemde çokça zulümler işlenmiştir. Ebû Hanîfe, Emeviler'in adil yöneticisi Ömer b. Abdulaziz (ö. 101/720) dönemini de görmüş. Ömer b. Abdulaziz'in adaletli yönetiminden sonra Emeviler'in zulüm dönemi tekrar baş göstermiş ve o da kaçınılmaz olarak bu zulümlere yeniden maruz kalmıştır. Fakat o, bu zulümlere aldırış etmeden, herhangi bir menfaat beklentisi içine girmeden ve hiçbir korkuya da kapılmadan hem tavizsiz bir şekilde siyasî meseleleri değerlendirmiş hem de tarihte silinmez bir tutum ortaya koymuştur.

İmam Ebû Hanîfe gençliğini hem ticaretle uğraşarak (Zorlu, 2013, s. 22) hem de öğrenimine devam ederek geçirmiş ve başta Arapça, Edebiyat, Sarf ve Nahiv olmak üzere muhtelif ilim dallarında kendini yetiştirmiş bir âlimdir. Toplumun takdirini kazanmasında; verdiği fetvaların çoğu zaman haklı görülmesi, fitnelere bulaşmaması, takvası ve ilimdeki otoriterliği etkili olmuştur (Özel, 2015, s. 21). Dolayisıyla o, sergilediği takva, ortaya koyduğu feraset, neşrettiği ilmî dürüstlük, isabet ettiği görüşler, mevcut iktidarlara karşı olan tavizsiz duruşu ve ticaretten kazandığıyla ilmî faaliyetleri destekleyerek halkın büyük sevgisini kazandı.

İmam Azam'ın yetiştiği bölge, müslim-gayrı müslim birçok fikrî ve itikadî firkanın bulunduğu, itikatla ilgili birçok tartışmanın yapıldığı ve Rey ehlinin bulunduğu bir yerdi. Dindar bir ailenin çocuğu olan Ebû Hanîfe de zaman zaman bu dinî ve fikrî mücadelelere katılmıştır. Onun yaşadığı yer ve çağda hem Harici ve Mu'tezile gibi birçok itikadî firka yaşamış hem de bir sürü amelî mezhep ortaya çıkmıştır. O ortamda Ebû Hanîfe, doğruları savunarak sadece bir fikıh mezhebinin kurucusu olarak kalmayıp aynı zamanda Ehl-i Sünnet itikadının önemli bir temsilcisi olan Maturidilik ekolunun da temelini atanlardan biri olmuştur. İtikadî mezheplerin teşekkül dönemine yetişmesi sebebiyle ilahî sıfatlar, kader, büyük günah işleyenin durumu ve tekfir gibi meseleler üzerinde Mu'tezile, Cebriye, Şia ve Hariciler gibi değişik firkalara mensup âlimlerle tartışmalar yapmış, savunduğu görüşlerle Ehl-i Sünnet inancının oluşmasına zemin hazırlayan ilk âlimler arasında yer almıştır (Özel, 2015, s. 22).

\section{Ebû Hanîfe'ye Göre Yöneticinin Seçilme Şekli ve Meşruluk Kriteri}

Yönetim meselesi, İslam âlimleri arasında önemli konu olarak varlığını devam ettirmiş bir meseledir. $\mathrm{Bu}$ mesele, genelde imamet veya hilafet kavramları ile ifade edilmiştir. İslam düşünce tarihinde siyaset denilen imamet veya hilafetle ilgili tartışmaların odak noktası, yönetimin kaynağının ne olduğu ve yönetici denilen halife veya imamın hangi kritere göre belirleneceği meselesidir. Başka bir ifade ile Müslümanları en çok meşgul eden konu, Hz. Peygamber'den sonra gelecek devlet başkanının nassla mı yoksa seçimle mi belirleneceği? (Santi, 1995, s. 320-330) sorusu oluşturmuştur. Devlet başkanının belirlenmesi konusundaki anlaşmazlık, tarihsel olarak İslam dünyasının en büyük kitlesi olan Sünnî öğreti ile Şiî öğreti arasında meydana gelmiştir. Aslında Ehl-i Sünnet ulemasının öngördükleri yöneticinin göreve gelme şekli, Şiî İmamet anlayışına endekslidir. Yani Sünnîlerin siyaset felsefesi, Şiî siyasetini eleştirerek var olmuştur. Mezhepler arasında otoritenin kaynağına yönelik yapılan tartışmalar,

IBAD Sosyal Bilimler Dergisi, (Özel Say1), 2019 
yöneticinin göreve gelme şeklini belirlemiştir. Ancak İslam'da, yönetime dair yapılan bu tartışmalar, tarihsel olarak iki döneme ayrılmaktadır.

Birincisi, ilk dört halife dönemi denilen dönemdir ki, bu dönem için meşruiyet sorununu tartışan genelde Şia ekolüdür. Şia'ya göre, halife nass ve tayinle seçilir. Bu seçim șekli ile seçilen tek bir halife var. O da Hz. Ali'dir. Ondan önceki halifeler nass ve tayinle seçilmedikleri için meşru halifeler değildir. Fakat Şia ekolünün dışında, Ehl-i Sünnet de dâhil genelde mezhepler o dönemin meşruiyetini tartışmamıştır. Onlar, Şia'nın öngördüğü "nass ve tayini” eleştirirken (Köse, 2009, s. 294 vd.), alternatif olarak "biat ve seçim" esası savunmuşlardır (el-Bakıllanî, 1947, s. 178; Udeh, 1982, s. 145; Aydın, 1990, s. 188). Dolayısıyla onlara göre ilk dört halife, toplumun tercih ve biatı ile seçilmiş meşru halifelerdir (İbn Sa'd, trs., 3, s. 343; el-Maverdî, 1990, s. 44; İb Hazm, 1318, 4, s. 167; Senhurî, 2001, s. 129; Cin ve Akgündüz, 1996, 1, s. 189; Tuğ, 1993, 2, s.873).

İslam tarihinde ilk dört halifenin meşruiyet durumu, daha çok efdaliyet (en faziletli) kavramı üzerinde tartışılmıştır. Konu, ilk dört halifeden hangisi efdal (en faziletli) idi? Efdal varken mefdulün (daha az faziletlinin) imameti caiz midir? Efdaliyeti kim(ler) ve neye göre belirleyecektir? gibi sorularla gündeme gelmiştir. Bu konunun tartışılmasının ana sebebi; Şia'nın, Hz. Peygamber'den sonra en faziletli kişi olarak Hz. Ali'yi kabul etmiş olmasıdır. Yani onların, efdal (en faziletli ) olan Hz. Ali varken sahabenin, mefdul (daha az faziletli) olan diğer üç halifeyi seçmesi ile ilgili itirazları ve efdaliyyet gerekçelerini göstererek Hz. Ebûbekir, Hz. Ömer ve Hz. Osman'ın meşruiyetini yok etme gayretleridir. Şia'nın aksine, başta Ehl-i Sünnet olmak üzere diğer ekoller ise ilk üç halifenin faziletlerini ileri sürerek (el-Bakıllani, s. 178) onların, meşru olduğunu ortaya koymuşlardır (el-Pezdevî, 1980, s. 270; en- Nesefî, s. 1993, 2, s. 443). Bu yöntemi takip eden âlimlerden biri de Ebû Hanîfe'dir. İmam Ebû Hanîfe ilk üç halifenin meşruluğunu kanıtlamak üzere şunları söyler: "Hz. Peygamber'den sonra ümmetin en faziletlisi sırasıyla dört raşit halifedir. Ona göre Hz. Peygamber, kendisinden sonra Hz. Ebûbekir ve Hz. Ömer'e uyulmasını emretmiş ve kendisi vefat etmeden önce Hz. Ebûbekir'e insanlara namaz kıldırmasını buyurmuş olduğundan ümmet, Hz. Peygamber'den sonra Hz. Ebûbekir'i halife seçmiştir. Onun tavsiyesiyle Hz. Ömer, onun da tesis ettiği şura neticesinde Hz. Osman seçildi. İmam Azam'a göre fazilet sıralamasında, dört halifeden sonra Aşere-i Mübeşşere gelir. Zira Hz. Peygamber, on kişinin cennetlik olduğunu isimleriyle bildirmiştir. Dolayisıyla Hz. Osman ve Hz. Ali'den teberri etmemek, ikisini de dost bilmek ve işlerini Allah'a havale etmek gerekmektedir. Ayrıca ona göre Hz. Ali, katıldığı savaşlarda meşru halife olarak haklı idi. Ona karşı savaşanlar ise hatalı idiler. İmama göre, Talha, Zübeyr ve Hz. Aişe hakkında susup olayı kurcalamamak gerekmektedir" (Ebû Hanife, 2018, s. 55-62; Beyazizade, 2000, s. 140-143). Dolayısıyla burada İmam Azam Ebû Hanîfe, meşruluk kriteri olarak toplumun seçim ve biatını kabul ettiği için her dört halifeyi hem meşru hem de hilafetteki sıralamayı fazilet sıralaması olarak kabul etmiştir.

İkincisi ise, ilk dört halifeden sonraki bütün dönemleri kapsamaktadır. Aslında bu dönemler için meşruiyet kavramı iki farklı anlamda kullanılmaktadır. İlk olarak, bu dönemde halifenin yönetime gelme şeklidir ki, ne Şia'nın iddia ettiği gibi 'nass ve tayin' ne de diğerlerinin ileri sürdüğü gibi 'seçim ve biat' vardır (Kapar, 1998, s. 15). Dolayısıyla, bu dönemde seçilen hiçbir devlet başkanı, genelde ulema ve ekoller tarafından yönetime gelme şekli açısından meşru olarak kabul edilmemiştir. Sonra ise, öyle veya böyle herhangi bir yol ve nedenle yönetime gelen veya yönetici olan kişilerin adalete ve hukuka bağlılığı oranında meşruiyetleri ele alınmıştır. Dolayısıyla ulema, yönetime gelme şekillerine bakılmaksızın bu yöneticileri, adalet ve hukuka bağlılık açısından meşruiyete tabi tutmuş ve hukuka bağlı kaldıkça ve adaleti takip ettikçe meşru (Kutlu, 2003, s. 29), aksi halde gayrimeşru addedilmişlerdir (Aydın, 2018, s. 95-111).

Ehl-i Sünnet'in hem itikadî hem de fikhî alanda en önemli ulemasından olan Ebû Hanife'nin halifeler için kabul ettiği yönetime gelme şekli "seçim ve biat"tır. Ona göre, ümmetin seçim ve onayı ile gelmeyen ve biatini almayan bir yönetici meşru bir yönetici değildir (es-Saymerî, 1405/1985, s. 68). Yani yönetici, halkın yönetime katılımı olan şura ile seçilmeli ve yine halkın onayı olan biatı almalı ve yönetimde olduğu müddetçe adalet üzere olmalıdır ki, meşru kabul edilsin. Bu şartları taşımayan bir yönetim ve yöneticiyi Ebû Hanîfe meşru kabul etmemiştir. Ona göre, istişare ve biat yoluyla değil de güç ve silah yoluyla hilafeti ele geçirip ve daha sonra da adet yerini bulsun kabilinden alınan biatler geçerli değildir. Meşru halife, ehl-i reyin (görüşs sahiplerinin) istişaresiyle, halkın da katılımıyla seçilir. Bunu da 
İmam-1 Azam, halife Ebû Cafer Mansur'la olan tartışmasında ortaya koymuş ve ona şöyle demiştir: "Siz yönetime, ehil insanların fikir birliğine başvurarak değil, gayrimeşru bir yolla seçildiniz. Oysaki yönetim, müminlerin icma ve istişaresiyle mümkündür. Misal Hz. Ebûbekir, Yemenlilerin onayı kendisine ulaşıncaya kadar toplumu yönetmekten -meşru olmaz düşüncesiyle- elini çekmiştir”' (el-Kerderî, 1981, s. 296). Dolayısıyla Ebû Hanîfe, yaşadığı dönemde Emevi ve Abbasi yöneticilerini, yönetime gelme şekli açısından meşru halifeler olarak kabul etmemiştir (Ebû Hanife, s. 38; el-Cessas, 1947, 1, s. 86). Ancak toplumun düzen ve ahengini sağlamak adına onları, adalet ve hukuka bağlılıkları noktasında meşru halifeler olarak kabul etmiştir. Bu görüş ve düşüncesiyle o, anarşiye meydan vermeden ve toplumu da büyük zararlara maruz bırakmadan hem zulme karşı çıkmış hem bireyin hukukunu korumuş hem de toplumun düzenini sağlamıştır.

\section{Ebû Hanîfe'nin Siyasi Tutumu}

Tabiatı itibariyle insan ve onların oluşturduğu toplumlar her an uyarılmaya ihtiyaç duyan bir yapıda yaratılmış ve oluşturulmuş olduklarından, Yüce Allah tarafindan her daim uyarıcı olarak onlara peygamberler gönderilmiştir. Peygamberlik tarihi açısında şüphesiz son uyarıcı $\mathrm{Hz}$. Muhammed (s.a.s.)'dir. Ondan sonra ise Allah, bu uyarı görevini genelde tüm Müslümanlara özelde ise ulema (âlimler) ve ümeraya (yöneticiler) yüklemiştir. Yani İslam dinine göre Yüce Allah, genelde bütün Müslümanlara ve özelde Müslüman idareci ve bilginlere "iyiliği emretme ve kötülükten sakındırma" (Al-i İmran, 3/104) sorumluluğunu yüklemiştir ki, onlardan biri de İmam Azam Ebû Hanîfe'dir. Hayatı boyunca $\mathrm{o}$, bir âlim ve aydın olarak bu sorumluluğun bilincinde olarak hareket etmiş ve toplumsal görevini yerine getirmiştir (Ebû Hanife, s. 43). Ebû Hanîfe, zaman ve zemin, kişi ve statü gözetmeksizin iyiliği emretme ve kötülükten sakındırma görevini hem bir farz olarak algılamış hem de onu hiçbir menfaat ve endişe içine girmeden yerine getirmiştir. Dolayısıyla İmam-1 Azam, adaletli davranmayan zalim ve fasık yönetim ve yöneticilere karşı İslâmî bilinç ve sorumluluğunu bu farzın bir parçası olarak ifa etmiştir (İslamoğlu, 2009, s. 243).

Genel olarak İslam dini, Müslümanların birliğine ve beraberliğine fazla önem vermiş ve toplumdan ayrılmanın bireysel, toplumsal ve siyasî sakıncalarına çeşitli naslarla temas etmiştir. Mesela, Kur'an'da şöyle denilmiştir: "Hep birlikte Allah' ın ipine sarılın, ayrılmayın" (Al-i İmran, 3/103). Başka bir ayette şu ifadeler kullanılmıştır: "Birbirinizle çekişmeyin, yoksa korkuya kapılırsınız, gücünüz gider" (Enfal, 8/46). Diğer bir ayette ise Müslümanlar şu tarzda uyarılmıştır: "Kendilerine açık deliller geldikten sonra ayrllı̆g düşüp ihtilaf edenler gibi olmayın" (Al-i İmran, 3/105). Kur'an'ın ifade ettikleriyle paralel bir şekilde Hz. Peygamber de şöyle buyurmuş̧ur: "Allah ümmetimi dalalette birleştirmez. Allah'ın (yardım) eli cemaat üzerindedir" (Tirmizî, "Fiten", 7). Başka bir hadiste ise şöyle demiştir: "Cemaatten bir karış kadar ayrılan kimse İslam'ın boyunduruğunu boynundan çıkarmış olur" (Tirmizî,, "Emsal”, 3) . Bu ayet ve hadisler hem topluma hem de toplumun önder ve âlimlerine toplumsal birlik, beraberlik ve bütünlüğün ne kadar önemli olduğu bilincini vermektedir. Dinin kazandırdığı bu bilinçten hareketle ve Müslümanların birlik ve bütünlüğünü muhafaza etmek gayesiyle Ebû Hanîfe, sosyo-politik yapıyı değerlendirmiş ve dinî meseleleri yorumlamıştır. Mesela o, son derece muttaki ve abid bir insan olarak yaşamakla birlikte, ameli imandan ayırmak suretiyle, büyük günah işleyenlerin dinden çıkmadıklarını ifade ederek ve ahirette azap görüp görmeyeceklerini Allah'a havale ederek parçalanmış toplumsal yapıyı korumuş ve tahkim etmiştir (Ebû Hanife, s. 43). Çünkü İslam'ın ilk dönemlerinde bu konular üzerinde büyük tartışmalar söz konusu olmuştur. Büyük günah işleyenlerin dinden çıktığını ileri süren Harici, Mu'tezile, Kaderiyye firkaları ile bu görüşte olmayan Ehl-i Sünnet mensupları arasında ciddi tartışmalar varmış. Ebû Hanîfe bu görüşleriyle, iman ve amel ayrımına giderek amellerden doğan ayrılık ve o ayrilıktan kaynaklanan toplumsal parçalanmayı önlemiş olmuş. Ayrıca o, Kelime-i Şehadeti getiren herkesi mümin kabul ederek ve bütün Müslümanların iman konusunda eşit olduklarını savunarak toplumsal eşitliği sağlamış ve böylece yeni Müslüman olanlara karşı ikinci sınıf Müslüman muamelesi yapılmasını ve onlardan cizye adı altında vergilerin alınmasını önlemiştir (Ebû Hanife, s. 67). Bu yaklaşımlardan dolayı İmam Ebû Hanîfe'yi, ilk ciddi Sünnî toplumsal ve siyaset teorisyenlerinden biri olarak sunmak mümkündür.

Ebû Hanîfe'nin ortaya koyduğu görüşlerin, İslam toplumunda oluşturduğu pratik faydaya Mevdudi şu ifadelerle değinmiştir: "Bu akide, Müslümanların sosyal yapısını bozulmaktan ve parçalanmaktan kurtarmıştır. Zaten birçok fırkaya ayrılıp dağılmış olan İslam ümmetini yeni yeni firkalara bölünmekten, 
karşı1ıklı nefret hisleri duymaktan, düşmanlıktan ve birbirleriyle çatışmaktan uzaklaştırmış ve bu sayede İslam camiası, ahlâkî bozukluğa düşmekten ve lakayt olmaktan masum kalmıştır. Karışıklık ve fitne devrinde Ebû Hanîfe'nin tanzim ve tertip ettiği ve temelini attığı Maturidî itikadı üzerine, zamanın vaziyetini de göz önünde bulundurmak suretiyle derinlemesine düşünüp dikkatle durduğumuzda bu hareket tarzı ve düşünüş biçiminin hem o devirde hem de günümüzde ne kadar büyük, güzel, tutarlı ve münasip bir hareket tarzı olduğunu görürüz" (el-Mevdudi, trs., s. 332).

İslam âlimleri, iyiliği emretme ve kötülükten sakındırma görevi ifa edilirken toplumun birlik ve beraberliği için yöneticilere "itaat" etmenin üzerinde önemle durmuşlardır. Onlar, yöneticilere itaatin temeline: "Ey iman edenler! Allah'a itaat edin, Resulüne ve sizden olan ulu'l-emre de itaat edin. Ĕger bir hususta anlaşmazlığa düsserseniz -Allah'a ve ahirete gerçekten inanıyorsanız- onu Allah'a ve Resulü'ne götürün, bu hem hayırl hem de netice bakımından daha güzeldir," (Nisa, 4/59) ayetini yerleştirirler (Sarıkaya, 1994, s. 11 vd.). Ayette ifade edildiği gibi Allah, yöneticilere itaati emretmektedir. Ulu'l-emr olan yöneticilere itaatin tüm tartışmaları, bu ayette mevcuttur. Ayette ifade edilen "ulu'l-emr" kavramı, yönetimin en üst kademesine hamledilmekle birlikte, çoğul sığasına bakıldığında yönetim kademesinde bulunan (el-Maturidî, Te'vilat, 2005, 3, s. 263) herkesi kapsamaktadır (Yazır, 1993, 2, s. 1376). Yani ayetteki ifade, genel olarak bir alt kademedekilere emir verenleri, özel olarak da yönetimin üst kademesindekileri içermektedir.

Âlimler, bu ayette Yüce Allah ve Hz. Peygamber hakkında: "ati'u (itaat ediniz)" emrinin ayrı ayrı ifade edildiği halde yöneticiler için tekrarlanmamasını şu tarzda dillendirirler: Yüce Allah'a ve Hz. Peygamber'e itaat, şartsız olduğu halde yöneticilere ise şartlıdır. Yani Allah ve peygamberinin emirlerine aykırı düşmeyen hususlarda onlara itaat söz konusudur (Nürsi, Emirdağ Lahikası, 2001, s. 484). Yüce Allah'a (Kur'an'a) ve Hz. Peygamber'e (Sünnete) aykırı olmayan konularda yöneticilere itaat etmek, İslam Müslümanların asli görevi olarak telakki edilmiştir. Zira âlimlere göre, Kur'an ve Sünnet'in sınırları içerisinde ulu'l-emre itaat etmek şarttır. Bunun en belirgin göstergesi ayette, anlaşmazlığa düşülen konularda Yüce Allah'ın ve Hz. Peygamber'in hakem kılınmış olmasıdır (el-Maturidî, Te'vilat, 2005, 3, s. 264). Dolayısıyla itaat prensibi büsbütün kayıtsız ve şartsız değildir. Müslüman olmak ve İslâmî hükümlerle hükmetmek şartıyla yöneticilere itaat etmek farz olur. Bu yüzden İslam siyasetinin temeli, hukukun üstünlügü ilkesine dayandırılmaktadır. Çünkü bu hukuk, dokunulmazlığın ve imtiyazın olmadığı bir hukuktur.

Fakat ulu'l-emr, Müslüman değilse veya Allah ve Resulü'nün emirlerine aykırı hüküm verir veya onlara uymayan bir davranışta bulunursa ona itaat etmek gerekir mi? Genelde bir prensip olarak İslam âlimleri, Kur'an ve Sünnet'e aykırı düşen konularda, hiç kimseye itaati şart koşmazlar (Yazır, 2, s. 1374-6). Yani onlara göre, bir yönetici hem Müslüman değilse veya İslam'dan ayrılırsa, hem de Müslüman olup esir olur veya adaletten ayrılırsa onlara itaat edilmez. Aslında İslam Tarihi boyunca genelde fakihler, en üst yönetici olarak halifenin gayr-i Müslimlerden olma durumunu pek tartışmamışlardı. Çünkü Kur'an'da, kâfirin müminler üzerinde velayet hakk1 yoktur (Nisa, 4/141), denilmektedir. Ancak gerçek problem, yönetimde iken, Müslüman bir yöneticinin adaletten ayrılması söz konusu olunca ona karşı nasıl bir tutum takınılacağı meselesidir. Doğrusu bu sorun, genelde İslam ulemasının, özelde ise Ebû Hanîfe'nin siyasî tutumunu belirleyen temel soru ve düğ̈m noktasıdır. İmam Ebû Hanîfe, imama karşı kıyam edilip edilmemesi, Dört Raşit Halife'nin durumu, Hz. Ali ve Hz. Osman'la ilgili yapılan tartışmalar hakkındaki mütalaasını, siyasi fırka ve tarafların birbirlerine karşı olan silahlı mücadeleleri hakkındaki düşüncelerini yoğun bir şekilde beyan eden ilk âlimlerden biridir (el-Karî, 1979, s. 169) Dolayısıyla, onun siyasî tutumunu belirlemek ve ortaya koymak bugünkü Müslümanlar için de önemlidir.

Ebû Hanîfe'nin hayatı tarihsel olarak ele alındığında, onun dört halifeden sonraki Müslüman yöneticilere karşı olan tutumunu iki ş̧ekilde değerlendirmek mümkündür. Birincisi, onlar seçim ve biatle seçilmemelerine rağmen İmam Azam, Kur'an'a ve Hz. Peygamber'in Sünneti'ne aykırı düşmeyen durumlarda yöneticilerin karar ve davranışlarını benimsemiş ve onlara itaat etmiştir. Dolayısıyla Ebû Hanîfe'yi, sürekli olarak sadece siyasete muhalif olan bir konumda görmek ve göstermek yanlış olur. Örnek, Abbasi halifesi Ebû'l Seffah'a biat ediyor (es-Saymerî, 1, s. 128-9) ve siyasetçilerin arkasında namaz k1liyor (Ebû Hanife, s. 45).

İkincisi, Ebû Hanîfe, Allah'ın ve Hz. Peygamber'in emirlerine aykırı hüküm veren veya onlara aykırı bir davranışta bulunan, yani hukuku ihlal eden ve adalete aykırı davranan yöneticilere ise itaat etmemiş ve 
onların emirlerini uygulamamıştır. Ancak Ebû Hanîfe, zulmeden ve kebairi (büyük günahlar) işleyen idarecilerin yöneticiliğini kabul etmemekle beraber içtimaî işlerin yürütülmesi ve kaosun oluşmaması için adaletsiz halifenin adaletli kadısının verdiği emirleri hoş görmüş ve bu noktada sorumluluğu bireylerin kendisine yüklemiştir. Yalnız burada yöneticilere itaat etmemekle isyan etmenin farklı şeyler olduğunu bilmekte fayda vardır. Ebû Hanîfe'nin, siyasetçilerin yanlış hüküm ve davranışlarına karşı olan itaatsizliği, farklı iki şekilde tezahür etmiştir.

İlk olarak, pasif muhalefet şeklindedir ki, her hangi bir dinî taviz vermeden ve sosyal dokuyu bozmadan, toplumsal görev ve sorumlulukları yerine getirmektir. Aslında bu tarz bir muhalefetle Ebû Hanîfe, hem yöneticilerin yanlışlıklarını dile getirmiş hem de kendisine verilen görev ve hediyeleri reddetmiş̧ir. Dolayisıyla O, hem Emeviler hem de Abbasiler devrinde potansiyel bir tehlike olarak algılanmış ve birtakım baskılara maruz kalmıştır. Yani her ne kadar yöneticiler, onun halk nezdindeki itibarından yararlanarak kendi taraflarına çekmek istedilerse de $\mathrm{O}$, hiçbir dönemde kendisine yapılan idarî teklifleri kabul etmemiş ve bu tutumundan dolayı birtakım işkenceye maruz bırakılmıştır (İbn Esir, trs., 5, s. 559).

İslam toplumlarında ulemanın hem toplumsal düzeyde toplumla yatay hem de siyasî düzeyde otoriteyle dikey ilişkisi söz konusu olmuştur. Bir İslam âlimi olarak Ebû Hanîfe, gerek yatay seviyede dinî oluşumlarla gerekse dikey düzeyde siyasî güçlerle aktif muhalefet ederek ve fitne, isyan ve kaos çıkarmadan zaman zaman pasif bir şekilde muhalefet etmiş bir alimdir. Bu muhalefeti fitne ve isyandan ayıran husus şudur: Muhalefette, toplumu tehdit eden şeylerin reddedilmesiyle içtimaî yapının huzuru, sağlığı ve işlerliği hedef iken, fitne ve isyanda ise, toplumda mevcut olan hastalığın tedavi yöntemi sağlıksız olduğu için toplumsal yapının tamamen yok olması söz konusu olabilir (Lewis, 1997, s. 114). Ayrıca fitne ve isyanda sonuçların çerçevesi ve nihai noktası hesaplanamayabilir. Onun için Müslümanlar kolay kolay isyan ve silahlı mücadeleye girişmemişler ve girişenlere de taraftar olmamışlardır. Zira din, zararlarından dolayı şiddetli bir şekilde isyan, fitne ve anarşiden alıkoymaktadır (Nürsi, Müdafaalar, 2013, s. 540).

İslam Tarihi boyunca başta Cemel ve Sıffin savaşları olmak üzere Müslümanlar arasında meydan gelen kanlı ve acı tecrübeler, idareye karşı çıkmakla halkın daha zararlı çıktığı, isyan edenlerin başarılı olma ihtimalinin daha zor olduğunu ve genelde idarî mekanizmanın daha kuvvetli olduğu gerçeğinden hareketle, Müslümanların yöneticilere itaat etmekten başka bir çaresi kalmadığını göstermiştir. Bundan dolayı, genelde "asayişi muhafaza", "yöneticilere itaat", "cemaate bağll1ık" esasları benimsenmiş̦tir (Sarmış, 2010, s. 277-298). Ayrıca İslâmî fırkalardan bir kısmı "emr-i bil'l-ma'ruf ve nehyi ani'lmünker" yöntemiyle, "huruc", "kıyam" ve "cihat" gibi mefhumları kullanarak giriștikleri mücadeleler sebebiyle müminlerin daha büyük acı ve 1stıraplara maruz kalması, ağır bedeller ödemesi ve onlar karşısında yöneticiler, elindeki gücü kullanarak isyan edenleri sefil bir duruma düşürmesi ve idarecilerin tahakkümlerine maruz kalması nedeniyle ümmetin "sabır", "temkin", "tedbir" esaslarına sığınmak zorunda kalmıştır. Bundan dolayı İmam-1 Azam Ebû Hanîfe de asayişi muhafaza ve toplumsal birliği koruma adına kendisine yapılan her türlü muameleyi sabır ve şükürle karşılamıştır. Zira bu tutum, siyaset literatüründe "pasif direniş", "sivil itaatsizlik" (Uyanık, 2015, s. 131), "müspet hareket", "manevî cihat" veya "pozitif siyaset" olarak nitelenmektedir.

Genel olarak Müslümanların geleneğinde egemen olan düşünce, yönetime karşı silahlı mücadele vermenin uygun görülmediği şeklindedir. Yöneticiler günahkâr ve zalim olsa da daha büyük fitne ve zulümlere neden olmamak için var olan yöneticilere itaat edilir, arkalarında namaz kılınır ve onlarla beraber cihada iştirak edilir. Bu genel anlayışla paralel olarak İmam Azam Ebû Hanîfe, zalim de olsa, mümin olan yöneticilerin arkasında namaz kılmayı uygun bulmuş ve şöyle bir görüş ortaya koymuştur: "Senin mükâfatın sana, onun günahı da kendisinedir" (Beyazizade, s. 144-146). Burada Ebû Hanîfe, yöneticilerin şahsi hatalarıyla kamuya ait yanlışlıkları ayırarak hem toplumun düzenini sağlamış hem de vicdanî sorumluluklarını yerine getirmiştir (Uyanık, s. 131).

Diğeri ise, aktif muhalefet tarzıdır ki, buna isyan, kıyam, huruç, maddî cihat gibi isimler de verilmektedir. İmam Ebû Hanîfe, zaman zaman bu muhalefeti hem teorik hem de maddî olarak desteklemiştir. Fakat kendisi aktif olarak ne herhangi bir harekette bulunmuş ve ne de herhangi bir harekete katılmıştır. Ancak $\mathrm{O}$, hem verdiği fetvalarla hem de yaptığı maddî yardımlarla meydana gelen aktif muhalefeti zaman zaman desteklemiştir. Derslerinde firsat buldukça iktidarı tenkit etmiş, hatta isyan 
eden Zeyd b. Ali (ö. 122/740)'nin (Batur, 2018, s. 217) imamlığına zımnen biat ederek malî destekte bulunmuştur. Hz. Ali'nin torunlarından Muhammed en-Nefsü'z-Zekiye (ö. 145/762) ile kardeşi İbrahim'in Abbasiler'e karşı kıyam ederek şehit olmaları durumunda Ebû Hanîfe, açıkça iktidarı tenkit etmiş, bu yüzden kırbaçlanmış, hapse atılmış ve işkence görmüştür (el-İ́sfehanî, trs., s. 378). Zira o, hem Abbasi Halifesi Mansur'a karşı isyan eden Muhammed Nefsu'z-Zekiyye'yi desteklemiş (Ebû Zehra, trs., s. 363) hem de insanları onun kardeşi olan İbrahim'le beraber ayaklanmaya çağırmış ve ona biat etmek üzere insanları teşvik etmiş ve cesaretlendirmiştir. Öyle ki, onunla birlikte isyan etmenin elli veya yetmiş defa hac ibadetini yapmaktan daha faziletli olduğunu dile getirmiş̧ir. Hatta bu konuda Ebû İshak enNizari adındaki bir şahsa: "Bana göre kardeşin İbrahim'i desteklemek, kâfirlerle cihattan daha hayırlıdır," (el-Cessas, 1, s. 81) demiş ve onu zalim idareciye karşı mücadele etmeye teşvik etmiştir. İmam Ebû Hanîfe, bir taraftan insanları ona yardım etmeye ve katılmaya teşvik ederken (Atalan, 2005, s. 157-168) diğer bir tarafta ise Ebû Mansur'un en büyük komutanı olan el-Hasan b. Kahtaba'y1, Muhammed ve İbrahim'e karşı mücadele etmekten alıkoymuş ve onun, halife Mansur'un yanına giderek bu savaşa kesinlikle katılmayacağını, ölse de bu iki şahsa karşı savaşmayacağını bildirmesini sağlamıştır (Ebû Zehra, 1981, s. 53-55).

Genel olarak Ebû Hanîfe, imama itaat etme ve ona karşı isyan etme konusunda çok temkinli ve tedbirli davranmıştır. Bunun sebebi, Hz. Hüseyin ve ailesinin başına gelen feci olaylar gibi hadiselerin tekrar vuku bulmaması ve Kufeliler'e güvenmemiş olmasıdır. Nitekim Zeyd b. Ali'nin kıyamı hakkında şu ifadeleri kullanmıştır: "Eğer, gerçekten insanların onunla birlikte olacağını ve onu yardımsız bırakmayacağını bilsem, onunla beraber olup muhalifleriyle savaşırdım. Çünkü gerçek halife ve imam odur. Yalnız endişe ediyorum ki, atası olan Hz. Hüseyin gibi, onu da yalnız bırakacaklardır. Ama mal ve mülkümle ona yardım ediyorum ki, bununla kendisine muhalefet edene karşı güçlensin" (İbn Sa'd, s. 368; Reşit Paşa, 2002, s. 259-272; Nevin, 1990, s. 290). Başka bir rivayette de şunları söylemiştir: "Zeyd b. Ali'nin bu çıkışı, Resülullah'ın Bedir günündeki çıkışına benziyor” (et-Taberî, 1967, 6, s. 183). Fakat kendisine Zeyd ile birlikte niçin savaşa katılmadığı sorulduğunda ise, bu yanıtı vermiştir: "Beni ondan alıkoyan, halkın yanımdaki emanetleridir" (İbn Sa'd, s. 368).

\section{Ebû Hanîfe'ye Göre Hukuk-Siyaset İlişkisi}

İslam siyaset tarihinde Şia mezhebi dışında genelde ulema, devlet başkanlarının ehl-i hal ve'l-akd denilen görüşs sahiplerinin seçimi ve halkın onayı denilen biatla yönetici olmaları gerektiği hususunda hemfikirdirler. Fakat ilk dört halifeden sonra devlet başkanlığına geçen yöneticilerin, yönetime gelme şekli şura usullü ve biat temelli olmadığından, onların seçilmeleri çoğunlukla meşru kabul edilmemiştir. Çünkü onlar zorla, güç kullanarak ve fiilî durumlar oluşturarak devletin başına geçmiş ve ulema da kendilerini defakto olarak bu durumun içinde bulmuşlardır. Âlimler, zorla devleti eline geçiren yöneticiler ile hukuku uygulama ve kendi sorumluluklarını yerine getirme paradoksuyla karşı karşıya kalmışlardır. Yani onlar hem vicdanî sorumlulukla hukukun uygulanmasını hem de bu uygulamanın üstünde duran yöneticilere hukukun tatbik edilmesi çelişkisiyle muhatap olmuşlardır. Şüphesiz bu çıkmazı en iyi aşmaya çalışanlardan biri âlim ve fakih İmam Ebû Hanîfe olmuştur.

Genel olarak İslam âlimleri, işledikleri hatalardan dolayı halifeleri, hukuk önünde diğer insanlarla eşit kabul etmeyi tercih etmiş ve bu tercihlerini de birtakım nasslara (hücürat, 49/13) ve Hz. Peygamber'in uygulamalarına dayandırmışlardır. Ancak onlar, hukuk kurallarının genelliğine ve herkes için söz konusu olduğuna inanmış olsa da, bazı suçlardan dolayı halifenin cezalandırılması konusunda görüş ayrılığına düşmüşlerdir. Dolayısıyla yöneticilerin adaletsizlik ve hatalarına yaklaşım iki farklı bakış açısıyla değerlendirilmiştir. Bunlardan birincisi, Ebû Hanîfe'nin görüşüdür. Ona göre halife, zina etmek ve içki içmek gibi şahsî suçlardan dolayı cezalandırılamaz. Zira bu, onun bu cezalandırılmayı hak etmediği anlamına gelmez, aksine onu cezalandırma imkânının bulunmaması nedeniyledir. Çünkü halife, başkalarının üzerinde velayet hakkına sahip iken, başkasının onun üzerinde herhangi bir velayet hakkı yoktur ki, onu cezalandırsın. Ayrıca onun bu cezalandırmayı kabul etmesi aklen mümkün değildir. Eğer o, cezasının uygulanmasını kabul etmeyecek olursa, o zaman cezayı uygulamak imkânsızlaşır. Zira hukukçulara göre vacip, imkânsız olduğu zaman artık vacip olma niteliğini kaybeder. Dolayısıyla halifeye uygulanması gereken ceza düşer (İbn Humam, trs., 6, s. 160).

Adam öldürmek ve yaralamak gibi başka kişilerin haklarıyla ilgili bulunan suçlara gelince Ebû Hanîfe, halifenin bunlara karşılık cezalandırılması gerektiği görüşündedir. Çünkü böyle bir cezanın 
uygulanmasını isteme hakkı, kendisine karşı suç işlenen kimsenin veya onun velilerinindir. Buna göre halife, bu türden bir suç işleyecek olursa, hakkın asıl sahipleri, cezanın uygulanmasını isteme hakkına sahiptir. Bunun uygulanması için de yargıdan ve toplumdan güç alırlar (İbn Humam, trs., 6, s. 160-1).

İkincisi: Fakihlerin büyük bir çoğunluğunun (cumhurun) kabul ettiği görüştür. Onlar, suçlar arasında herhangi bir ayırım yapmazlar. İster Allah'ın hakları ile ilgili isterse bireyin hakları ile ilgili bulunsun, halife veya imamın işlediği bütün suçlardan sorumlu olacağı görüşündedirler. Çünkü nasslar geneldir, suçlar da herkes için haramdır. Bu "herkes" kavramının içerisine devlet başkanı da girer. Buna göre devlet başkanı bile olsa, işlediği suçlardan dolayı cezalandırılır. Bu fakihler, Ebû Hanîfe'nin yaptığı gibi, cezanın uygulanma imkânına bakmazlar. Çünkü suçluların cezasını uygulama görev ve yetkisi, yalnızca halifeye ait olan bir şey değildir. Buna göre halife, bir suç işleyecek ve bu suçun cezasıyla hüküm giyecek olursa, kendisine ve ümmete temsilcilik eden ve suçun cezasını uygulama yetkisine sahip bulunan kimselerden biri, bu suçun cezasını kendisine uygular (es-Sabunî, 1982, s. 126-7).

Sonuç olarak, genelde birçok İslam âlimin yaklaşımında görüldüğü gibi, İmam Ebû Hanîfe'nin siyaset ve siyasetçilere dair görüş ve tutumu konusunda dikkat çeken hususlar; yöneticilere itaat ve asayişi muhafazadır. Onların yanlışlıklarına (münker) yönelik tavrı ise, bir hadiste mealen ifade edildiği gibi, önce eliyle düzeltmek, buna güç yetirilmiyorsa sözlü olarak karşı çıkmak, o da mümkün değilse kalben hoş görmemek (Müslim, "İman", 78; Tirmizî, "Fiten", 11) ve onlar tarafından yapılan taciz ve sıkıntılara karşı ise sabırlı davranmaktır. O, yaşadığı her dönemde Kur'an ve Sünnet'in ölçülerini esas alarak siyasî dürüşünü ortaya koymuş, eleştirilerini yapmış ve hatta kendisini susturmak için her bir dönemde, yöneticiler tarafından kendisine teklif edilen para, makam ve maddî şeylere tenezzül etmemiştir. Çünkü Ebû Hanîfe'ye göre, bu teklifleri kabul etmek, dinî ve ahlâkî düşüncelerinden vazgeçmek anlamına gelirdi. Onun için o, mümkün mertebe siyasilerden ve siyasetçilerin verdiği makam ve hediyelerden uzak durmuştur.

\section{Sonuç}

Bütün dinlerde olduğu gibi İslam'da da tarihi süreç içerisinde birçok itikadî ve fikhî ekol ortaya çıkmıştır. İslam dünyasının en büyük inanç mezhebi olan Ehl-i Sünnet'in günümüzde yaşayan dört büyük fikhî ekolünden biri Hanifî mezhebidir. Şüphesiz bu mezhebin kurucusu İmam Azam Ebû Hanîfe'dir. Ebû Hanîfe, dinde zamanın otoritelerinden biri, fikıhta Hanefi mezhebinin kurucusu ve itikatta Maturidî ekolunun temelini atan kişilerden biridir. O, İslam siyasal tarihinde Emevi ve Abbasiler dönemlerine şahit olmuş ve o iki dönemde de muhtelif baskı ve zulümlere maruz kalmıştır. Fakat İmam, bu zulümlere aldırmadan hem tavizsiz bir şekilde siyasî meselelere adil ve mutedil çözümler getirmiş hem de dinin öngördüğü önemli ve etkin bir tavır ortaya koyarak tarihte silinmez bir iz bırakmıştır.

Genel olarak Müslümanlar, halifenin seçim usulü olarak şura ve biatı kabul etmişlerdir. Ebû Hanîfe de, devlet başkanının seçimi için şura ve biat denilen halk onayını esas almış ve ilk dört halifenin seçilmesini tartışmasız olarak meşru görmüştür. Fakat o, ilk dört halifeden sonraki dönemin siyasetçilerini, bu yöntemle seçilmedikleri için, yönetime gelme şeklini meşru görmemekle beraber, ancak onları hukuka ve adalete bağl11kkları açısından meşru görmüştür. $O$, bu görüş ve düşüncesiyle, anarşiye meydan vermeden ve toplumu da zarara uğratmadan hem yöneticilerin meşruluğunu tartışmış hem yanlışlıklarını eleştirmiş hem bireyin hukukunu korumuş hem de toplumun düzenini sağlamıştır. Dolayısıyla Ebû Hanîfe, bu şekilde hem iyiliği emretmek hem de kötülüğü engellemek denilen toplumsal sorumluluk bilincini yerine getirmiştir.

İslam dini toplumsal birlik ve bütünlüğün önemini sürekli olarak bireylere telkin eden bir dindir. Dinin kazandırdığı bu bilinçten hareketle, Müslümanların birlik ve bütünlügünü muhafaza etmek gayesiyle Ebû Hanîfe, dinî meseleleri yorumlayarak parçalanmış toplumsal yapıyı korumaya çalışmış bir âlimdir. Onun oluşturduğu inanç ve hukuk sayesinde, Müslümanların sosyal yapısı bozulmaktan ve parçalanmaktan kurtulmuş ve böylece o, zaten birçok firkaya ayrılmış olan İslam ümmetini yeni yeni firkalara bölünmekten, karşılıklı nefret hislerini duymaktan ve birbirleriyle çatışmaktan kurtarmıştır.

İmam Ebû Hanîfe, toplumsal bütünlüğün en önemli unsuru olan ulu'l-emre (yöneticiler) itaat etmenin çok önemli olduğu üzerinde durmuş ve Kur'an ile Sünnet'in sınırları içerisinde onlara itaat etmenin farz olduğunu dile getirmiştir. Ona göre, İslâmî hükümlerle hükmettikçe ve adaletten ayrılmadıkça ulu'l-emre itaat etmek gerekir. Fakat Ebû Hanîfe, Allah ve Resulü'nün emirlerine aykırı hüküm veren, onlara aykırı 
bir davranışta bulunan ve adaleti sağlamayan yöneticilere ise itaat etmemiş ve onların emirlerini uygulamamıștır. Bu tutumunu da genelde pasif muhalefet olarak, zaman zaman da aktif muhalefeti destekleyerek ortaya koymuştur. Pasif muhalefet, her hangi bir dinî taviz vermeden ve sosyal dokuyu bozmadan, toplumsal görev ve sorumlulukları yerine getirmektir ki, İmam çoğunlukla bunu tercih etmiştir. Fakat o, yöneticilere itaat etme ve onlara karşı isyan etme konusunda çok temkinli ve tedbirli davranmakla beraber, hem verdiği fetvalarla hem de yaptığı maddî yardımlarla meydana gelen aktif muhalefeti bazen teşvik etmiş bazen de desteklemiştir. Bu görüş ve tutumuyla İmam Azam, siyaseti hukukun üstünlüğü ilkesine, hukuku da, dokunulmazlığın ve imtiyazın olmadığı bir ahlâkî ilkeye dayandırmıştır.

Ebû Hanîfe sadece siyasî açıdan değil, hukukî açıdan da yöneticilerin yaptıklarını adalet açısından değerlendirmeye tabi tutmuştur. Ona göre, halife kendisini ilgilendiren şahsî suçlardan dolayı cezalandırılamaz. $\mathrm{Bu}$, onun cezalandırılmayı hak etmediği anlamına gelmez, aksine onu cezalandırma imkânının bulunmaması anlamına gelir. Çünkü eğer halife, kendisine cezasının uygulanmasını kabul etmezse, o zaman cezayı uygulamak imkânsızlaşır. Fakat başka kişilerin haklarıyla ilgili suçlar konusunda halifenin cezalandırılması gerektiği görüşündedir. Çünkü böyle bir cezanın uygulanmasını isteme hakk1, kendisine karşı suç işlenen kimsenin veya onun velilerinindir. Buna göre halife, bu türden bir suç işleyecek olursa, hakkın asıl sahipleri, cezanın uygulanmasını isteme hakkına sahiptir. Bunun uygulanması için de yargıdan ve toplumdan güçlerini alırlar.

Sonuç olarak, İmam Azam Ebû Hanîfe'nin siyaset ve siyasetçilere dair görüş ve tutumu konusunda dikkat çeken hususlar; yöneticilere itaat, asayişi muhafaza ve cemaate bağlılıktır. Onların yanlışlıklarına (münker) yönelik tavrı ise önce eliyle düzeltmek, buna güç yetirilmiyorsa dil (söz) ile reddetmek, bu da mümkün değilse kalben hoş görmemek ve onlardan gelen eziyetlere karşı ise sabretmektir. Ebû Hanîfe'nin hayatı incelendiğinde, yerine göre bu tavırların hepsini görmek mümkündür. O kime, nerede, ne zaman ve ne şekilde davrandığını ince hesaplayarak toplumsal dokuya zarar vermeden fikirler ortaya koymuş ve tutumlar takınmıştır. Dolayısıyla onun hayatında görülen tutum değişikliği, onun istikrarsızlığı anlamına gelmez. Aksine, tabiatı itibariyle siyasetin değişken bir alan olmasından kaynaklanmaktadır. Onun tutum değişikliği, sistemlerin farklılığına ve yöneticilerin muhtelif uygulamalarına bağlanabilir. Dolayısıyla bizim de hem tarihî tecrübeden hem de Ebû Hanîfe gibi ulemanın hayatından ders alarak yirminci yüzyılda, Müslümanlara karşı geliştirilen psiko-sosyolojik, teknolojik ve fiziksel harp teknikleri karşısında yapılacak olan hak arama bilincini geliştirerek ve şiddete başvurmadan, fikrine güvenerek, aleni bir şekilde, kamu vicdanına hitap ederek, düşmanlıkları derinleştirmek yerine, problemleri gidermeyi hedef alan hesaplanabilir ve hesap verilebilir barışç1 tutumlar ortaya koymamız gerekir.

Bilgilendirme / Acknowledgement: Bu çalışma $2^{\text {nd }}$ International Congress on New Horizons in Education and Social Sciences (ICES-2019)'da sözlü bildiri olarak sunulmuş çalışmanın genişletilmiş ve gözden geçirilmiş halidir.

\section{KAYNAKÇA}

Aliyyu'l-Kari. (1979). Fıkh-ı Ekber Şerhi. (trc. Yunus Vehbi Yavuz). İstanbul: Çağnı Yayınları.

Atalan, M. (2006). Ebû Hanîfe ve Alioğulları. Dinî Araştırmalar Dergisi, 8, 24.

Aydın, A. (2018). Devlet İdaresine Dair Konulara Fıkıh Eserlerinde Az Yer Verilmesini İbn Haldun'nun Realist Siyaset Teorisi Ekseninde Değerlendirme. Türkiye'de Din Eğitimi Araştırmaları Dergisi, $6,95-111$.

Aydın, M. A. (1990). İslam Hukukunda Devlet Başkanının Tayini Usulü. İstanbul: Osmanlı Araştırmaları.

Bağdadî, H. (trs.). Tarihu Bağdad. Beyrut: Daru'l-Kutubi'l-ïlmiyye. 
Bakıllanî, K. E. (1947). et-Temhid. Kahire: Matbaatu'l-Behiyye.

Batur, M. R. (2018). Zeydilik ve Selefilik Arasinda İbnü'l-Vezir. Ankara: Gece Akademi.

Beyazizade, A. E. (2000). İmam-ı Azam Ebû Hanîfe'nin İtikadî Görüşleri. (çev. İlyas Çelebi).

İstanbul: MÜ İlahiyat Vakfı Yayınları.

Cessas, E. (1947). Ahkamu'l-Kur'an. Kahire: Matbaatu'l-Behiyye.

Cin, H.-Akgündüz, A. (1996). Türk Hukuk Tarihi. İstanbul: Osmanlı Araştırmaları Vakfı Yayınları.

Ebû'l-Ferec, A. (trs.). Makati'l-Talibin. (nşr. Ahmed Sakr). Kahire: Daru İhyai'l-Kütübi'l-Arabiyye.

Ebû Hanife, N. (2018). İmam-ı Â'zam'in Beş Eseri. (trc. Mustafa Öz). İstanbul: İfav Yayınları.

Ebû Zehra, M. (trs.). İslam'da İtikadî, Siyasî ve Fıkhî Mezhepler Tarihi. İstanbul: Yeni Şafak

Yayınları.

Ebû Zehra, M. (1981. Ebû Hanîfe. (çev. Osman Keskioğlu). İstanbul: Can Kitapevi.

Gazalî, E. H. (1898). İhya'u Ulumi'd-Din. İstanbul.

Gazalî, E. H. (1351). Nasihatü'l-Mülük. (neşr. Celaleddin Humeyî). Tahran.

Hamidullah, M. (1993). İslam Peygamberi. (çev. Salih Tuğ). İstanbul: İrfan Yayınları.

İbn Esir, İ. (1407/1987). el-Kamil fi 't-Tarih. Beyrut: Dâru'l-Kütübi'l-İlmiyye,

İbn Humam, K. (trs.). Şerhu Fethi'l-Kadir. Beyrut: Dâru'l-Kütübi'l-İlmiyye.

İbn Sa'd, M. (trs.). et-Tabakatu'l-Kubra. Beyrut: Dâru'l-Kütübi'l-İlmiyye.

İslamoğlu, M. (2009). İmamlar ve Sultanlar. İstanbul: Düşün Yayıncılık.

Kapar, M. A. (1998). Islam 'ın Illk Döneminde Bey'at ve Seçim Sistemi. İstanbul: Beyan Yayınları.

Katib, A. (2010). Sünni Siyasal Düşüncesinin Gelişimi Demokratik Hilâfete Doğru. (trc. Muhammed Coşkun). İstanbul: Mana Yayınları.

Kerderî, H. (1981). Menakibu'l-İmamu'l-Azam. Beyrut: Daru'l-Kütübü'l-Arabî.

Kutlu, S. (2002). Türklerin İslamlaşma Sürecinde Mürcie ve Tesirleri. Ankara: Türkiye Diyanet Vakfi Yayınları.

Kutlu, S. (2003). Bilinen ve Bilinmeyen Yönleriyle Imam Mâtürîdî ve Mâtürîdîlik. Ankara: Kitâbiyât Yayınları.

Köse, H.M. (2009). Siyaset. TDV İslâm Ansiklopedisi (DIA) içinde (c. 37, ss. 294-299). İstanbul: Diyanet Vakfi Yayınları.

Lewis, B. (1997). İslam'in Siyasal Söylemi, (The Politicial Language of Islam). (çev. Ünsal Özkay). İstanbul: Phoneix Yayınları.

Maturidî, E. M. (2005). Te'vilatu'l-Kur'an, (Te'vîlatu Ehl-i Sünne). Beyrut: Daru'l-Kutubi'l-İlmiyye.

Maverdî, E. H. (1990). el-Ahkamu’s-Sultaniye. Beyrut: Daru'l-Kütübü'l-Arabî.

Mevdudi, E. (trs.). Hilafet ve Saltanat. (trc. Ali Gencel). İstanbul: Hilal Yayınları.

Nesefî, E. M. (1993). Tabsiratu'l-Edille. (thk. Hüseyin Atay). Ankara: Türkiye Diyanet Vakfi Yayınları.

Nevin, A. M. (1990). İslam Siyasi Düşüncesinde Muhalefet. (çev. Vecdi Akyüz). İstanbul: İz Yayıncılık.

Nursi, B. S. (2001). Emirdă̆ Lahikası. İstanbul: Zehra Yayıncılık.

Nursi, B. S. (2013). İçtimai Dersler. İstanbul: Zehra Yayınc1lık.

Nursi, B. S. (2012). Müdafaalar. İstanbul: Zehra Yayınc1lı. 
Nursi, B. S. (2013). Tarihçe-i Hayat. İstanbul: Zehra Yayıncılık.

Oral, O. (2018). Mâtüridi'de Din-Siyaset Illişkileri ve Yönetim İlkeleri. Kayseri: I. Uluslararası Sosyal Bilimler Kongresi.

Özel, M. (2015). İmam Ebû Hanîfe ve Hanefî Mezhebi. Ankara: DİP Yayınları.

Pezdevî, E. Y. (1980). Ehl-i Sünnet Akaidi. (trc. Şerafeddin Gölcük). İstanbul: Kayıhan Yayınları.

Reşit Paşa, H. Ş. A. (2002). Ebû Hanîfe'nin Siyaset Anlayışı. (sad. Mevlüt Uyanık). İslami Araştırmalar Dergisi, 1, (1-2), 259-272.

Sabunî, N. (1982). Maturidiyye Akaidi. (çev. Bekir Topaloğlu). Ankara: Diyanet İşleri Bşk.

Santi, P. (1995). İslam'ın Başlangıcında Belli Başlı Siyasi ve Felsefi Akımlar. (trc. M. Sait Yazıcıoğlu). AÜIF İslamî İlimler Enstitüsü Dergisi, (5), 320-330.

Sarmış, İ. (2010). Şura'dan Saltanata, Teokrasiye ve Laisizme Yönetim. İstanbul: Düşün Yayınları.

Sarkkaya, M. S. (1994). Ehl-i Sünnet'in Devlet Telakkisinde İki Mesele: İdari Sistem, Devlet Reisine İtaat. SD ̈̈IF Dergisi, (10), 1-17.

Saymerî, K. E. A. (1405/1985). Ahbâru Ebî Hanîfe ve Ashâbihî. Âlemü'l-Kütüb.

Senhurî, A. (2001). Fikhu'l-Hilafe ve Tatavvuruha. Beyrut: Daru'l-Kütübü'l-Arabî.

Taberî, E. C. M. (1967). Tarihu'l-Umem ve'l-Muluk. (thk. Muhammed Ebû'l-Fazl İbrahim). Beyrut: Daru'l-Kütübü'l-Arabî.

Taftazanî, S. (trs.). Şerhu'l-Makasıd. (thk. Abdurrahman Umeyra). Beyrut: Dâru'l-Kütübi'l- 'Ilmiyye.

Udeh, A. (1982). İslam ve Siyasi Durumumuz. (trc. Beşir Eryarsoy). İstanbul: Pınar Yayınları.

Uyanı,, M. (2015). Ebû Hanîfe ve Said Nursi'de Sivil İtaatsizlik. İstanbul: Ufuk Yayınları.

Yazır, E. M. H. (1979). Hak Dini Kur'an Dili. İstanbul: Eser Neşriyat.

Zorlu, C. (2013). Âlim ve Muhalif. İstanbul: İz Yayınc1lı. 